\title{
Notes
}

\section{Interest Analysis Applied to Corporations: The Unprincipled Use of A Choice of Law Method}

\author{
Jack L. Goldsmith III
}

Choice of law litigation often involves large corporations, ${ }^{1}$ because corporate activity frequently implicates the laws of several states. In theory, choice of law rules apply indiscriminately to persons and corporations. ${ }^{2}$ The modern interest analysis approach to choice of law, ${ }^{3}$ however, at-

1. The large, multi-state corporation serves as the working paradigm of this Note. This Note's critique of interest analysis in the corporate context will not apply to purely domestic corporations, which, by the nature of their activity, are usually not involved in choice of law litigation.

2. More specifically, the same choice of law rules that govern personal affairs also govern the external affairs of a corporation, such as contracts, asset transfers, and torts. RESTATEMENT (SECOND) of Conflict of LAws § 301 (1971) [hereinafter RESTATEMENT (SECOND)] ("rights and liabilities of a corporation with respect to a third person that arise from a corporate act of a sort that can likewise be done by an individual are determined by the same choice-of-law principles as are applicable to non-corporate parties"); Reese \& Kaufman, The Law Governing Corporate Affairs: Choice of Law and the Impact of Full Faith and Credit, 58 Colum. L. Rev. 1118, 1120 (1958).

The internal affairs of a corporation, which include corporate organization and structure as well as the relationship between shareholders and managers, are governed by the law of the place of incorporation. See First Nat'l City Bank v. Banco Para el Comercio Exterior de Cuba, 462 U.S. 611, 621 (1983); Restatement (Second), supra, at $\S 302$. See generally Kozyris, Corporate Wars and Chaice of Law, 1985 Duke L.J. 1 (extensive discussion of internal affairs doctrine).

3. American choice of law doctrine has undergone a well-noted transformation in the past thirty years. The traditional vested rights approach has been replaced in many states by one of a variety of modern methods. See generally E. SCOLES \& P. HAY, Conflict OF LAws $\$ \S 2.4-.17$ (1982) (outlining history of recent choice of law revolution). The traditional approach, embodied in the RESTATEMENT OF CONFLICT OF LAws $\S \S 377-90$ (1934) [hereinafter RESTATEMENT], generally applies the law of the place where the legal right in question vests. See L. BRILMAYER, AN INTroduction to JURISDICTION IN THE FEDERAL SYSTEM 218-21 (1986). Modern theories have developed along two general lines: the Second Restatement's "most significant relationship" test, discussed infra notes 7 \& 77; and interest analysis, the focus of this Note, which is explained in detail, infra notes 6-26 and accompanying text. 
tempts to assimilate corporations into a framework suited to individuals that fails to account for the special nature of corporate entities in reaching choice of law solutions. ${ }^{4}$ Consequently, although interest analysis seems neutral in application to corporations and persons, it actually operates to produce untoward results in the corporate context.

This Note argues that interest analysis cannot be applied to corporations in a principled manner. Section I explores the domicile-based presuppositions at the heart of interest analysis. Because interest analysis ascertains protective state interests on the basis of domicile, and because corporate contacts with a state do not translate well into domiciliary status, interest analysis fails to recognize important state interests in protecting corporations. Section II identifies the types of corporate contacts that should implicate the protection of state laws, and documents the variety of ways that interest analysis courts have undervalued these contacts in determining the "appropriate" array of state interests. While Section II implicitly develops a model of how interest analysis would have to operate in order to be fair to corporations, it does not suggest that interest analysis can coherently accommodate corporations. For as Section III shows, the inclusion of corporations in the interest calculus leads to unresolvable difficulties. Moreover, interest analysis as currently practiced allows extraneous anti-corporate factors to influence the purportedly neutral evaluation of state interests.

4. A nascent but growing literature details the pernicious effects of treating corporations like persons in the eyes of the law, and suggests a more entity-specific approach. See M. DAN-COHEN, Rights, Persons, and Organizations: A Legal Theory for Bureaucratic Society (1986); C. Stone, Where the Law Ends: The Social Control of Corporate Behavior (1975); see also Stewart, Organizational Jurisprudence (Book Review), 101 HARv. L. Rev. 371 (1987) (reviewing Dan-Cohen's book and outlining various theories of organization). These scholars argue that the law frequently breaks down when applied to corporations because it inevitably fails to assimilate corporations into pre-existing individualistic legal structures. See M. DAN-CoHEN, supra, at 5. The most prominent branch of organization theory focuses on corporate rights and responsibilities. See, e.g., C. Stone, supra; Coffee, "No Soul to Damn: No Body to Kick": An Unscandalized Inquiry into the Problem of Corporate Punishment, 79 MICH. L. REV. 386 (1981); Kraakman, Gatekeepers: The Anatomy of a Third-Party Enforcement Strategy, 2 J.L. Econ. \& ORG. 53 (1986). These commentators believe that the distinctive organizational features of corporations must be considered in designing legal controls for corporate conduct.

This Note builds on the perception by organization theorists of "the need to correct the law's prevailing disregard of the unique characteristics of organizations." Stewart, supra, at 373. However, this Note focuses not on corporate responsibility, but rather on the manner in which the application of a seemingly neutral choice of law system treats corporations inequitably.

5. This Note specifically critiques interest analysis as applied to corporations in tort and tortrelated contexts. It emphasizes tort law because (1) interest analysis has most frequently replaced the traditional approach in the tort context, see T. DE Boer, Beyond Lex Loci Delicri 10 (1987); Juenger, Conflict of Laws: A Critique of Interest Analysis, 32 AM. J. CoMP. L. 1, 12 (1984) thereinafter Juenger, Conflict of Laws]; and (2) most judicial decisions and academic discussions concerning interest analysis focus on torts, see Juenger, What Now?, 46 OHio Sr. L.J. 509, 514 (1985). Because tort and tort-related laws vary from state to state, the choice of law determination is crucial to the outcome of a case. 


\section{The Interest Analysis Bias Against Recognition of State INTERESTS IN CORPORATIONS}

Interest analysis subsumes a variety of related choice of law techniques. ${ }^{8}$ These methods differ more in name than in substance, however, especially when contrasted with the traditional learning. Each method generally provides that a court faced with a choice of law problem should initially look to the policies expressed in the purportedly conflicting state laws in order to assess the extent of each state's interest ${ }^{7}$ in having its law apply to the particular case. ${ }^{8}$ Additionally, each method agrees on the process for identifying and resolving false conflicts. ${ }^{\circ}$ Agreement collapses, however, concerning how courts should resolve true conflicts. ${ }^{10}$

6. Corr, Interest Analysis and Choice of Law: The Dubious Dominance of Domicile, 1983 UTAH L. Rev. 651, 653 n.10; Reppy, Eclecticism in Choice of Law: Hybrid Method or Mishmash?, 34 MerCER L. Rev. 645, 647 (1983). These related techniques all grow out of the seminal work of Brainerd Currie. See generally B. CurRIE, Selected Essays on the Conflict of Laws (1963).

7. Several authors have attacked the interest analysis conception of state interests. See, e.g., Brilmayer, Interest Analysis and the Myth of Legislative Intent, 78 MrcH. L. REv. 392 (1980) (attacking theory that "interests" reflect legislative will); Ely, Choice of Law and the State's Interest in Protecting Its Own, 23 WM. \& MARY L. REv. 173 (1981) (attacking interest analysis' protect-thelocals orientation). This Note does not critique the interest analysis concept of state interests directly. Rather, it reads "interests" sympathetically in order to illustrate the unprincipled application of the concept to corporations. Generalizations about interest analysis must be made carefully, because courts frequently add their own variations and employ several choice of law methods, or combinations of different methods, in reaching their conclusions. See Reppy, supra note 6 (attacking "eclectic" approach in modern choice of law). Moreover, "[c]ourts have shown a distinct inability to distinguish [different choice of law theories and] ... often say they are using one theory when their opinions clearly show that they are using another." Smith, Choice of Law in the United States, 38 Hastings L.J. 1041, 1042 (1987). This Note will focus on what courts actually do rather than on what they say they are doing, and will consider as an example of interest analysis any case in which courts reach their conclusions through the identification and consideration of state interests.

The Second Restatement's "most significant relationship" test, see RESTATEMENT (SEcond), supra note 2 , at $\S 145$, presents special methodological difficulties when discussing interest analysis because courts often purport to invoke it while actually performing interest analysis, see, e.g., Murphy v. Colorado Aviation, 41 Colo. App. 237, 242, 588 P.2d 877, 880 (1978), or use it to break true conflicts in the course of an interest analysis, see, e.g., Griggs v. Riley, 489 S.W.2d 469 (Mo. App. 1972). In analyzing and criticizing interest analysis as applied to corporations, this Note will not consider the Second Restatement approach except when it is being invoked as a proxy for interest analysis. For a brief discussion of the application of this Note's critique to the Second Restatement, see infra note 77.

8. E. SCOLES \& P. HAY, supra note $3, \S 2.6$, at 17; Corr, supra note 6 , at 653.

9. Juenger, Conflict of Laws, supra note 5, at 13-14; Reppy, supra note 6, at 647 \& n.12. A false conflict reveals itself when an examination of the underlying policies of facially conflicting laws demonstrates that only one state has an interest in applying its law to the case. L. BRILMAYER, supra note 3, at 235-36. In such a case, the conflict is only apparent, and the court can without difficulty apply the law of the interested state. Id. The elimination of false conflicts reduces the number of cases in which courts must choose between competing laws. Many scholars consider this feature to be interest analysis' greatest achievement. J. Martin, Perspectives on Conflict of Laws: Choice of LAw 85 (1980); Ely, supra note 7, at 175-76, 195-96.

10. A true conflict exists if the first level examination of relevant state policies reveals that each state has an interest in applying its law to the case. At this stage, a second level of analysis is required to resolve the dispute. L. BRILMAYER, supra note 3, at 236-39. However, scholars generally agree that no one has yet established a satisfactory way to resolve true conflicts. Ely, supra note 7, at 176; von Mehren, Special Substantive Rules for Multistate Problems: Their Role and Significance in Contemporary Choice of Law Methodology, 88 HARv. L. REv. 347, 365-66 (1974). The most-prominent methods for resolving true conflicts include: "Currian" interest analysis, see B. GuRRIE, supra note 6, at 184 (apply forum law); Leflar's choice-influencing considerations, see Leflar, ChoiceInfluencing Considerations in Conflicts Law, 41 N.Y.U. L. REV. 267 (1966) (apply law which best 


\section{A. The Crucial Role of Domicile in Interest Analysis}

Interest analysts view the scope of a state law in terms of the power of a sovereign over its domiciliaries. ${ }^{11}$ Domicile expresses the unique ${ }^{12}$ relationship between an individual and a governmental unit. ${ }^{13}$ The domicile concept is necessary to establish a person's legal headquarters so that his or her legal status and various legal relationships can each be governed by one law. ${ }^{14}$ The law of a person's domicile regulates marriage, divorce, parent-child relationships, state taxes, voting rights, educational and health care benefits, probate, and intestate succession..$^{15}$

Interest analysis presupposes that each sovereign intends its laws to benefit only its domiciliaries and not out-of-staters similarly situated. ${ }^{16}$ For example, interest analysts believe that state legislatures design defendant-protecting laws, such as contributory negligence or limitation of damages, to protect only in-state defendants. ${ }^{17}$ This protect-the-locals conception forms a crucial element of interest analysis, for it narrows the scope of purportedly conflicting laws. Without such a mechanism to discount state interests in non-local litigants, all apparent conflicts would be true conflicts and interest analysis' primary achievement-the identification of false conflicts ${ }^{18}$ - would be diminished. ${ }^{19}$ Despite viewing state laws as

secures justice based on five choice-influencing considerations); comparative impairment, see Baxter, Choice of Law and the Federal System, 16 STAN. L. REv. 1 (1963) (apply law of state whose policies are most impaired if not applied); and the "most significant relationship" test, see RESTATEMENT (SECOND), supra note 2 , at $\S 145$ (apply law of state with most significant relationship to parties and occurrence).

11. L. BRILMAYER, supra note 3, at 234.

12. Each person has only one domicile. Restatement (SECOND), supra note 2, at $\S 11(2)$. "If la person could have more than one domicile], the concept of domicile could not be used to select the state whose law governs certain of the person's important legal interests." Id. at $\$ 11$ comment m (citation omitted).

13. Id. at $\S 11(1)$; E. Scoles \& P. HAY, supra note 3, at $\S 4.1$. For an account of the origin of the concept of domicile, see Nygh, The Reception of Domicil into English Private International Law, 1 Tasmanian U.L. Rev. 555 (1961).

14. E. Scoles \& P. HAY, supra note 3, at 4.1-4.3, 4.15. As Holmes stated, "what the law means by domicile is the one technically pre-eminent headquarters, which as a result either of fact or of fiction every person is compelled to have in order that by aid of it certain rights and duties which have been attached to it by the law may be determined." Bergner \& Engel Brewing Co. v. Dreyfus, 172 Mass. 154, 157, 51 N.E. 531, 532 (1898).

15. See E. Scoles \& P. HAY, supra note 3 , at $\$ 4.1$.

16. B. CURRIE, supra note 6 , at $89,270,292,417,705,724$; see also L. BRILMAYER, supra note 3 , at 240; Ely, supra note 7, at 173-75, 196-97.

17. See, e.g., Hurtado v. Superior Court, 11 Cal.3d 574, 581, 522 P.2d 666, 670, 114 Cal. Rptr. 106, 111-12 (1974).

18. For the definition of "false conflict," see supra note 9.

19. See Ely, supra note 7 , at $175-76$ (interest analysis impotent without methodological premise that states only interested in protecting their own); Reppy, supra note 6, at $647 \mathrm{n.12}$ ("lawmaker chauvinism ('our law is just for the benefit of our domiciliaries') is thus the heart of interest analysis, because without that approach, no false conflict could exist"). The central importance of this protectthe-locals premise cannot be overemphasized. If a state with a plaintiff-protecting rule has an interest in generating a victory for the plaintiff in a case regardless of the domicile of the plaintiff, then "all states with any connection with the case must be counted as interested and . . . the case therefore cannot be waved aside as involving a false or trivial conflict." Ely, supra note 7 , at 178 . On the other hand, if interests were defined in terms of geographical location rather than domicile, the method 
protecting only local domiciliaries, though, interest analysts do not limit state law protection territorially. Rather, the protection of state law "travels" with the individual ${ }^{20}$ and may apply to a transaction in a foreign state.

Interest analysts use domicile to assign litigants to particular states for the purpose of determining relevant state interests. In the great majority of cases, a court using interest analysis simply determines the domicile of the plaintiff and the defendant and then assigns to each party the law of that domicile in ascertaining each state's interest in applying its laws. ${ }^{21}$ However, interest analysis theory fails to articulate rigorously the type or level of contacts with a state needed to secure domiciliary status and thus the protection of state laws. ${ }^{22}$ Consequently, interest analysis courts also use residence, ${ }^{23}$ citizenship, ${ }^{24}$ and sometimes even employment within the state $^{25}$ as connecting factors to identify state protective interests. Interest analysts draw no distinction between "domicile" and its cognates" in this regard, ${ }^{28}$ because a state also has an interest in protecting persons with those domicile-like contacts that express a persistent and unique relationship with a state.

would constitute the functional equivalent of the territorialist First Restatement. Id. at 177. "Thus, the only way the [interest analysis] system can operate ... is by assuming that states are interested in applying their rules so as to generate victories for their own people in a way they are not interested in generating victories for others." Id. at 178.

20. This feature of interest analysis is a variation on the medieval personal law principle, which states that the law of a person's state follows and applies to the person's activities beyond that state. See R. Leflar, L. McDougal. \& R. Felix, American Conflicts Law 3-4 (1986); Guterman, The Principle of the Personality of Law in the Early Middle Ages: A Chapter in the Evolution of Western Legal Institutions and Ideas, 21 U. MiaMI L. REv. 259, 306-16 (1966). Interest analysts consider the law of a person's domicile somewhat analogously to a personal law for the purpose of determining the protective scope of a state's law and thus a state's interest. Technically, though, scholars who identify interest analysis with the medieval personal law principle, see, e.g., Juenger, Conflict of Laws, supra note 5, at 11-12,39, are incorrect. The personal law principle was employed as a jurisdiction-selecting method; the law of a person's home state applied to govern his or her personal capacities, regardless of whether or not the law benefitted the local. See, e.g., R. LEFLAR, L. MCDovgal \& R. Felix, supra, at 3; Guterman, supra, at 306-16. By contrast, interest analysis rejects jurisdiction-selecting rules and purports to assess the actual substantive scope of the laws in question. The concept of state interests works like a personal law only to the extent that the protection of a state's law vests in the domiciliary for the purpose of analyzing competing state interests.

21. Juenger, What Now?, supra note 5, at 39; Reppy, supra note 6, at 647 n.11.

22. L. BRILMAYER, supra note 3, at 240; see also Ely, supra note 7, at $173 \mathrm{n} .1$ (Currie never clarified "whether he meant to be talking about residence, domicile, citizenship, or "the state to which one belongs" "); Juenger, Conflict of Lau's, supra note 5, at 39 (interest analysts unable to describe with precision type of relationship between person and state necessary and sufficient to activate governmental interest).

23. See, e.g., Labree v. Major, 111 R.I. 657, 673, 306 A.2d 808, 817-18.(1973).

24. See, e.g., Baird v. Bell Helicopters Textron, 491 F. Supp. 1129, 1139, 1141 (N.D. Tex. 1980).

25. See, e.g., Allstate Ins. Co. v. Hague, 449 U.S. 302, 313-14 (1981) (plurality opinion).

26. See, e.g., B. CurRIE, supra note 6, at 292 (benefits of wrongful death statute "should be made available whenever those who are the objects of its protection are members of the community-i.e., residents or domiciliaries of the state") (emphasis added). 


\section{B. The Inapplicability of the Domicile Concept to Corporations}

The domicile concept used by interest analysts applies most naturally to persons. ${ }^{27}$ Most of the functions served by domicile with regard to persons do not apply to corporations. ${ }^{28}$ Corporations do not vote, divorce, or bequeath property to their children. Although some issues governed by personal domicile, such as personal jurisdiction and the power to tax and to regulate, are common to persons and corporations, a state derives its powers of adjudication and taxation over a corporation from business and incorporation contacts not related to domicile. ${ }^{29}$ While courts ${ }^{30}$ and schol$\operatorname{ars}^{31}$ sometimes refer to the relationship between a corporation and its state of incorporation as domicile, this attribution confounds corporate activities with those of individuals. ${ }^{32}$

27. Roman law first employed domicile as a concept akin to residence to govern municipal abligations and to establish personal jurisdiction of municipal courts. M. JACOBS, THE LAw of DOMich. $\S \S 1-12$ (1887); Nygh, supra note 13, at 555-57. In Anglo-American jurisprudence, the concept of domicile developed in England as a connecting factor employed to determine the law applicable to a variety of personal transactions and relationships such as succession to personal and real property. Id. at 565. It was later used to determine the law that governed personal status and capacities. Id. Scholars disagree about whether the Anglo-American concept of domicile originated in English common law or Roman civil law. See Francis, The Domicil of a Corporation, 38 YALE L.J. 335, 341 (1929). Today, the concept continues to serve primarily to identify the law governing personal transactions and relationships, especially family-oriented matters. See E. ScolEs \& P. HAY, supra note 3, at $\S 4$.

28. Restatement (Second), supra note 2 , at $\$ 11$ comment $l$; E. Scoles \& P. HAY, supra note 3 , at $\$ 4.46$.

29. Restatement (SeCOND), supra note 2, at $\$ 11$ comment $l$ ("it is both inaccurate and unnecessary to explain the existence of [the power to tax and to adjudicate] on the ground that the corporation has its domicil in the state of incorporation"). $A$ minimum contacts analysis establishes both the power to tax, see Miller Bros. v. Maryland, 347 U.S. 340, 344-45 (1954), and the power to adjudicate, see International Shoe v. Washington, 326 U.S. 310, 319-20 (1945), although the tax standard is easier to satisfy, see L. BRILMAYer, supra note 3, at 397.

30. See, e.g., Baird v. Bell Helicopters Textron, 491 F. Supp. 1129, 1137 (N.D. Tex. 1980).

31. See, e.g., Romano, Law as Product: Some Pieces of the Incorporation Puzzle, 1 J.L. EcoN. \& ORG. 225,280 (1985).

32. Restatement (Second), supra note 2 , at $\S 11$ comment $l$; H. Henn \& J. Alfxander, Laws of Corporations 153 (3d ed. 1983).

Domicile used to be more relevant in the corporate context than it is today. The First Restatement provided that a corporation had its domicile in the place of its incorporation and could not acquire a domicile in another state. RESTATEMENT, supra note 3 , at $\$ 41$. This view was grounded in the contemporary American common law notion that a corporation lacked existence outside of the state of its creation, although it could carry on business in other states. $1 \mathrm{~J}$. BEALE, A Treatise ON THE Conflict of Laws 228-29 (1935). See generally A. Farnsworth, The Residence and Domicil OF CORPORATIONs 58-59, 269-70 (1939) (discussing early twentieth century American common law views on corporate entity and corporate domicile). Even the First Restatement recognized that the nature of a corporation precluded it from acquiring a home and thus a domicile of choice; but corporate domicile was viewed as a necessary fiction to regulate certain aspects of corporate activity. RESTATEMENT, supra note 3 , at $\$ 41$ comment c. However, the rise of corporate entity theory, see Horwitz, Santa Clara Revisited: The Development of Corporate Theory, 88 W. VA. L. REv. 173 (1985), and the development of minimum contacts analysis, see cases cited supra note 29 , rendered irrelevant the concept of corporate domicile, as the Second Restatement eventually acknowledged, RESTATEMENT (SECOND), supra note 2 , at $\$ 11$ comment $l$.

The legal realists were among the first to articulate the incoherence of assimilating corporations into an individualistic domicile framework. See, e.g., W. CoOK, The Logical and Legal Bases of THE CONFI.ICT of LAws 207-10 (1942); Francis, supra note 27. It is therefore ironic that interest analy'sts, whose intellectual roots are firmly grounded in legal realism, see Dane, Vested Rights, "Vestedness," and Choice of Law, 96 YAL.E L.J. 1191, 1196-1201 (1987), have failed to grasp the problematic application of their domicile framework to corporations. 
Corporations by their nature do not fit well into the domiciliary framework. Domicile has two elements: physical presence in a place ${ }^{33}$ and specific intent to make a home there, ${ }^{34}$ neither of which can be ascribed neatly to a corporate entity. Corporations do not possess "presence" the way people do. ${ }^{35}$ The variety of corporate contacts with a state, such as incorporation, principal place of business, and doing business, are less tangible and more geographically dispersed than the contacts of a person with a state..$^{36}$ Moreover, the ascription of corporate intent raises problems not found in the individual context. ${ }^{37}$

Additionally, the domicile concept has an "all-or-nothing" character. ${ }^{38}$ The model of a person having one and only one permanent and specific residence correlates fairly well with reality. ${ }^{39}$ Corporations, however, do not fit this model well, especially when they are incorporated in one state, headquartered in another, have their principal place of business in a third, manufacture products in several others, and do business in many more states.

\section{Ignored Corporate Contacts That Should Trigger Protective State InTERests}

Interest analysis thus employs a concept of domicile that applies to individuals but not corporations. Domicile, though, is the contact that triggers state interests. Thus, because corporate contacts with a state-incorporation, principal place of business, and doing business-do not give rise to the domiciliary status needed to implicate a state's interest, interest analysis courts tend systematically to ignore or to attenuate state

33. RESTATEMENT (SECOND), supra note 2 , at $\$ 16$.

34. Id. at $\S 18$.

35. See, e.g., Thompson v. Horvath, 10 Ohio St. 2d 247, 251, 227 N.E.2d 225, 228 (1967) (corporation, unlike real person, has no physical presence); 1 W. FLETChER, GyClOPEdia of tHE LaW of Private Corporations $\S 7$ (rev. perm. ed. 1980) (same); Cohen, Transcendental Nonsense and the Functional Approach, 35 Colum. L. REv. 809, 811 (1935) ("'[n]obody has ever seen a corporation").

36. See R. Leflar, L. McDougal \& R. Felix, supta note 20, at 29 ("any corporation can be 'present' in several different states for various purposes and . . . the means of determining its 'presence' for different purposes are so variant that laying down a single body of rules for corporate domicile is impossible").

37. See M. Dan-Cohen, supra note 4, at 32-38; see also T. Donaldson, Corporations and MORAlity 21-23 (1982) (corporations act intentionally but lack analogue of individual intent); $C$. STONE, supra note 4, at 3, 35 (questioning coherence of corporate "mind").

38. See supra note 12 .

39. Some scholars argue that the purported uniqueness of personal domicile is increasingly a fiction. See Corr, supra note 6, at 668-71; Corson, Reform of Domicile Law for Application to Transients, Temporary Residents and Multi-Based Persons, 16 Colum. J.L. \& Soc. Prons. 327, 330 (1981); see also Texas v. Florida, 306 U.S. 398, 428-32 (1939) (Frankfurter, J., dissenting) (increase in mobility and intangible wealth undermines domicile assumption that individuals can be related to single place). The fact that a person's domicile changes over time does not prevent it from being unique at any particular moment. And even if the concept is increasingly fictional, it is still a necessary fiction required to govern personal status and transactions, see supra notes 14-15 and accompanying text, which is irrelevant in the corporate context, see supra notes 28-32 and accompanying text. 
interests in corporations. ${ }^{40}$ This Section analyzes the three types of corporate contacts with a state and demonstrates that courts have left corporations with these contacts out of the interest calculus. ${ }^{41}$

\section{A. State of Incorporation}

The state of incorporation creates the corporate entity as an incident to its sovereign powers. ${ }^{42}$ In so doing, the state establishes a legal personality capable of possessing rights and duties. Incorporation functions as a crucial contact in numerous jurisdictional and conflict of law contexts. For example, the law of the place of incorporation governs internal corporate affairs. ${ }^{43}$ Moreover, corporations qualify as citizens of the state of their incorporation for diversity jurisdiction purposes. ${ }^{44}$ Finally, the courts of a state can assert general personal jurisdiction over corporations incorporated in that state. ${ }^{45}$

The incorporation contact implicates many of the same state interests that the domicile connecting factor captures for individuals. ${ }^{48}$ Both an individual's and a corporation's legal personality-their "particular bundle of rights, powers, privileges, and duties"-are creatures of state law. ${ }^{47}$ The state of incorporation is thus a natural candidate to establish a personal protective law ${ }^{48}$ for a corporation, because it is the state that brings

40. As this Section will make clear, courts attenuate protective interests in corporations in a variety of ways. Most frequently, courts fail to recognize interests in corporations at all. Sometimes they discuss a state's interest in imposing liability on a corporation, and in a very few cases they mention a corporate-protecting interest but then proceed to discount it drastically. This Section attempts to explain and impose some structure on the variety of anti-corporate interest analysis decisions by showing that they all arise from the skewed domicile schema into which corporations do not fit.

41. As argued infra notes 49-51, 65-66,72 and accompanying text, these contacts implicate the - same concerns recognized by interest analysts in other contexts. However, because interest analysts (surprisingly) fail to state what it is about being a domiciliary that implicates state interests, see Corr, supra note 6, at 671; Ely, supra note 7, at 177, it would be impossible to prove conclusively by analogy with the domicile contact that these corporate contacts always establish state interests. Nonetheless, the point of this Section is that corporate contacts raise concerns in a state that are analogous to those recognized for individuals, thus rendering unexplained and unjustified the exclusion of corporations from the interest calculus.

Additionally, the argument in this Section does not claim that corporate contacts taken alone warrant the application of the contact state's law. Rather, the Section shows that, according to interest analysis principles, the contacts should give rise to interests to be considered in the overall interest calculation. The focus is on interest identification and consideration, the necessary predicates to a proper interest analysis. Interest analysts leave corporations out of this calculus without explanation.

42. 1 W. FletCHER, supra note 35 , at $\$ \$ 113-14$.

43. See supra note 2 .

44. 28 U.S.C. $\S 1332$ (c) (1982).

45. See Twitchell, The Myth of General Jurisdiction, 101 HARv. L. REv. 610, 633 \& n.111 (1987).

46. See R. Weintraub, Commentary on the Conflict of Laws 304 (1986) (state has interest in applying its defendant-protecting laws to corporation incorporated in state). Currie once recognized, without discussion, that states have legitimate interests in applying their protective tort laws to corporations incorporated within the state. See B. CURRIE, supra note 6, at 704.

47. Reese \& Kaufman, supra note 2, at 1122; see also Foley, Incorporation, Multiple Incorporation, and Choice of Law', 42 HARv. L. REv. 516, 518-19 (1929) ("[corporations] cannot, any more than human beings, enter into legal relations unless enabled to do so by law").

48. For a discussion of the personal law principle as used in the interest analysis context, see 
the corporation into existence and initially ascribes the corporation with personal capacities. ${ }^{49}$ The incorporation state also possesses instrumental revenue interests in its corporations: Many states derive enormous financial benefits from incorporation franchise $\operatorname{tax}^{5} \mathrm{~s}^{5 \rho}$ and are interested in protecting this revenue source..$^{\text {s1 }}$

Although courts sometimes refer to a corporation's place of incorporation as its domicile, ${ }^{52}$ they attenuate the significance of the law of the place of incorporation in calculating relevant state interests. Some courts fail even to mention the place of incorporation of corporate litigants, and neither analyze the relevant policies underlying the laws of the incorporation states nor discern the ignored states' interests in applying their laws to their corporations. ${ }^{\text {s3 }}$

Other courts at least mention the places of incorporation, but fail to consider the laws of those places in analyzing interests. ${ }^{54}$ For example, in

supra note 20.

49. In a purely domestic situation, a corporation would, as an incident of incorporation, be subject to and deserve the benefit of the tort laws of the state of its incorporation just as would a domiciliary individual. See 9 W. FLETCHER, supra note 35, at $\$ 4255$. The situation should be identical in the interstate context; interest analysis presents no reason why a state would have an interest in applying its protective tort laws to the foreign activity of one of its domiciliary individuals but not one of its corporations.

50. For example, Delaware, the most popular state of incorporation, derived $16 \%$ of its total revenues from incorporation franchise taxes in 1987. Labaton, Debate Over New Takeover Law, N.Y. Times, Feb. 1, 1988, at D4, col. 3.

51. The various parties in the debate concerning the effects of competition among states for the business of corporate charters agree that states strongly desire to "maximize revenues from corporate chartering." Macey \& Miller, Toward an Interest-Group Theory of Delaware Corporate Law, 65 Tex. L. Rev. 469,470 (1987). The incorporation debate concerns whether the financial and other benefits that states receive are in exchange for providing corporate laws that are favorable to management, see Cary, Federalism and Corporate Law: Reflections upon Delaware, 83 YALE L.J. 663, 665-66 (1974), or efficient, see R. WINTER, GOVERNMENT AND THE CoRPORATION 28-42 (1978). A state interested in providing favorable corporate laws in order to attract corporations and maximize revenue should have a concomitant interest in applying its favorable tort laws to protect its corporations. This interest in protecting revenue sources and preventing revenue drain is well recognized by interest analysts in other contexts. See infra notes 65-66, 72 and accompanying text; see also Corr, supra note 6, at 653 (recognizing state of incorporation's interest in preventing large judgments against its corporations).

52. See, e.g., Baird v. Bell Helicopters Textron, 491 F. Supp. 1129, 1137 (N.D. Tex. 1980).

53. See, e.g, Kaczmarek v. Allied Chem. Corp., 836 F.2d 1055 (7th Cir. 1987); Ambrose v. Illinois-Calif. Express, Inc., 151 Ariz. 527, 729 P.2d 331 (1986); Schlemmer v. Fireman's Fund Ins. Co., 292 Ark. 344, 730 S.W.2d 217 (1987); Wallis v. Mrs. Smith's Pie Co., 261 Ark. 622, 550 S.W.2d 453 (1977); Mitchell v. United Asbestos Corp., 100 Ill. App. 3d 485, 426 N.E.2d 350 (1981); Jagers v. Royal Indem. Co., 276 So. 2d 309 (La. 1973); Fox v. Morrison Motor Freight, Inc., 25 Ohio St. 2d 193, 267 N.E.2d 405, cert. denied, 403 U.S. 931 (1971); Griffith v. United Air Lines, 416 Pa. 1, 203 A.2d 796 (1964); Zelinger v. State Sand \& Gravel Co., 38 Wis. 2d 98, 156 N.W.2d 466 (1968).

54. Courts use a variety of methods to reduce the importance of the incorporation contact in interest analysis cases. Some courts proclaim without discussion that a state has no interest in applying its laws to a corporation whose only contact with the state is incorporation. For example, in Heavner v. Uniroyal, Inc., 63 N.J. 130, 141, 305 A.2d 412, 418 (1973), a product liability case with a statute of limitations choice of law issue, the New Jersey court stated-without explanation and without examining the policies of the laws of New Jersey - that the incorporation contact of defendant Uniroyal was insufficient to establish a New Jersey interest.

Other courts disclaim a state's interest in a corporation established under its laws because of the purportedly adventitious nature of the incorporation contact. See Seiderman v. American Inst. for Mental Studies, 667 F. Supp. 154, 158 (D.N.J. 1987) ("accident of having been incorporated in 
Turcotte v. Ford Motor Co. ${ }^{\mathbf{6 5}}$ a Rhode Island citizen filed a diversity suit against Ford, incorporated in Delaware, to recover for the wrongful death of his son arising from a car accident in Massachusetts. The First Circuit, using an "interest weighing" approach, framed the choice of law issue solely in terms of whether Massachusetts' limited wrongful death statute or Rhode Island's more generous one would apply. ${ }^{56}$ In so doing, the court failed to consider the relevant interests of Delaware, the state of defendant's incorporation. If a Delaware domiciliary rather than a Delaware corporation had been the defendant in a wrongful death action, an interest analysis court would have considered the policies underlying Delaware's law in performing the interest analysis calculation. ${ }^{57}$ Incorporation in the state, however, did not warrant the implication of that state's laws. ${ }^{58}$

\section{B. Principal Place of Business}

Federal law establishes that a corporation is also ${ }^{59}$ a citizen, for purposes of diversity jurisdiction, in the state of its "principal" place of business. ${ }^{60}$ Corporations have one and only one principal place of business. ${ }^{61}$ Courts have developed a number of tests to ascertain a corporation's principal place of business, ${ }^{62}$ but have a notoriously hard time doing so. ${ }^{63}$

Pennsylvania") (emphasis added); Estrada v. Potomac Elec. Power Co., 488 A.2d 1359, 1362 n.6 (D.C. App. 1985) ("the court is struck by the fortuity of defendant's state of incorporation") (emphasis added); Deemer v. Silk City Textile Mach. Co., 193 N.J. Super. 643, 650, 475 A.2d 648, 651-52 (App. Div. 1984) (distinguishing previous case in which New Jersey did not possess "any sufficient interest" in products liability action involving New Jersey corporation because "the only New Jersey contact was chance incorporation of the defendant") (emphasis added). To the contrary, though, the state of incorporation is not accidental. See Romano, supra note 31.

55. 494 F.2d 173 (1st Cir. 1974).

56. Id. at 179 .

57. See, e.g., Hurtado v. Superior Court, 11 Cal. 3d 574, 581, 522 P.2d 666, 670, 114 Cal. Rptr. 106,110 (1974) (en banc) (considering interests of defendant's domicile in wrongful death case). Cf. Labree v. Major, 111 R.I. 657, 673, 306 A.2d 808, 817-18 (1973) (looking to residence of both parties).

58. See also Pearce v. E.F. Hutton Group, Inc., 664 F. Supp. 1490 (D.D.C. 1987); Burley v. General Motors Corp., 650 F. Supp. 90 (D. Me. 1986); Camp v. Forwarders Transp., Inc., 537 F. Supp. 636 (C.D. Calif. 1982); Lewis v. Chemetron Corp., 448 F. Supp. 211 (W.D. Pa. 1978); Gordon v. Eastern Air Lines, Inc., 391 F. Supp. 31 (S.D.N.Y. 1975); Gravina v. Brunswick Corp., 338 F. Supp. 1 (D.R.I. 1972); Johnson v. Hertz Corp., 315 F. Supp. 302 (S.D.N.Y. 1970); Tiernan v. Westext Transp., Inc., 295 F. Supp. 1256 (D.R.I. 1969); Schwartz v. Consolidated Freightways Corp., 300 Minn. 487, 221 N.W.2d 665 (1974); Oltarsh v. Aetna Ins. Co., 15 N.Y.2d 111, 204 N.E.2d 622, 256 N.Y.S.2d 577 (1965).

59. See supra text accompanying note 44.

60. 28 U.S.C. $\S 1332$ (c) (1982). In addition, a court in the state of a corporation's principal place of business may assert general personal jurisdiction over the corporation. See Perkins v. Benguet Consol. Mining Co., 342 U.S. 437 (1952).

61. See, e.g., Celanese Corp. of Am. v. Vandalia Warehouse Corp., 424 F.2d 1176, 1178 (7th Cir. 1970).

62. Some courts follow the "nerve center" test, which focuses on the location of the executive and administrative functions of the corporation, see, e.g., Philip Morris, Inc. v. Sun Leasing Co., 371 F. Supp. 1233, 1234 (S.D.N.Y. 1974), while others employ the "center of operations" test, which emphasizes the production and service activity of the corporation, see, e.g., Kelly v. United States Steel Corp., 284 F.2d 850, 853 (3d Cir. 1960). See generally C. Wright, Law of Federal Courts 
With regard to large multi-state corporations, the concept of a principal place of business is often a fiction. ${ }^{64}$

The state that qualifies as a corporation's principal place of business should have an interest in that corporation's welfare. This contact implies a continuous and ubiquitous relationship with a state that benefits numerous state citizens both directly and indirectly, and should give rise to state interests in protecting the economic well-being of a corporation as a means toward regulating the state's economy, maximizing corporate tax revenues, and protecting in-state employees and creditors. ${ }^{65}$ These interests are grounded precisely in the kind of instrumental revenue concerns recognized by interest analysts in other contexts, such as preventing injured victims from becoming public charges, providing for a compensation pool for medical and other creditors, and preserving the integrity and economy of the forum's judicial process. ${ }^{66}$ Nonetheless, without examination most interest analysis courts either fail to disclose, ${ }^{67}$ or mention but ignore, ${ }^{68}$

104-05 (3d ed. 1976) (attempting to reconcile these two tests).

63. C. WRIGHT, supra note 62, at 104; Joiner, Corporations as Citizens of Every State Where They Do Business: A Needed Change in Diversity Jurisdiction, 70 JuDICATURE 291, 293-94 (1987).

64. Kelly, 284 F.2d at 853 ("The concept may get artificial in some cases as indeed it is in the case before us. This great corporation . . . has literally dozens of important places of business one of which we must pick . . . because the statute says so.") (footnote omitted); C. WRIGHT, supra note 62 , at 104 (assumption of only one principal place of business for large corporations "highly unrealistic").

65. See In re Air Crash Disaster Near Chicago, 644 F.2d 594, 614 (7th Cir.) ("California, as does every state, has a substantial interest in the economic health of corporations which do business within its borders. . . . California's interest is strong with regard to a rule disallowing punitive damages because such a rule protects the economic well-being of the corporations and therefore enhances the economic well-being of the state ....") (emphasis added), cert. denied sub nom. Lin v. American Airlines, 454 U.S. 878 (1981); see also Schulhof v. Northeast Cellulose, Inc., 545 F. Supp. 1200, 1206 (D. Mass. 1982) (state of principal place of business has interest in protecting its businesses from large liability); Deemer v. Silk City Textile Mach. Co., 193 N.J. Super. 643, 651, 475 A.2d 648, 652 (App. Div. 1984) (attenuating New Jersey's interest in applying its anti-defendant products liability law to corporaticn conducting manufacturing activities in state because application of law "would have the undesirable consequence of deterring the conduct of manufacturing operations in this state and would likely result in an unreasonable increase in litigation and thereby unduly burden [New Jersey's] courts"); Feldman v. Acapulco Princess Hotel, 137 Misc. 2d 878, 891-2, 520 N.Y.S.2d 477, 486 (1987) (Mexico's interest in protecting local hotel connected to interest in encouraging tourism and developing economy); of. Symeonides, Revolution and Counter-Revolution in American Conflicts Law: Is There a Middle Ground?, 46 OHo Sr. L. J. 549, 557 (1985) ("one cannot deny seriously that a state like Michigan has a great deal at stake in a products liability action against one of Michigan's auto industries").

66. See Allstate Ins. Co. v. Hague, 449 U.S. 302, 319 (1981) (plurality opinion) (state interest in keeping injured persons off welfare); B. CuRRIE, supra note 6, at 61,145 n.64, 150-51, 209-10, 701-02 (state interest in protecting local medical services and keeping indigents off welfare); $R$. WEINTRAUB, supra note 46, at 304-07 ("forum . . . has an interest in preserving the integrity and economy of its judicial process"); Brilmayer, Governmental Interest Analysis: A House Without Foundations, 46 Oнго ST. L. J. 459, 470-71 (1985) (state interest in keeping welfare bills as low as possible); Corr, supra note 6, at 652-63 (state interest most easily identifiable when financial, especially when loss of tax revenues is an issue); Juenger, Conflict of Laws, supra note 5, at 13 (state interest in protecting local creditors); Symeonides, supra note 65, at 559 (state interest in protecting local medical creditors and preventing indigents from becoming public wards).

67. See, e.g., Pearce v. E.F. Hutton Group, Inc., 664 F. Supp. 1490 (D.D.C. 1987); Johnson v. Hertz Corp., 315 F. Supp. 302 (S.D.N.Y. 1970); Murphy v. Colorado Aviation, 41 Colo. App. 237, 588 P.2d 877 (1978); Mitchell v. United Asbestos Corp., 100 Ill. App. 3d 485, 426 N.E.2d 350 (1981).

68. See, e.g., Kaczmarek v. Allied Chem. Corp., 836 F.2d 1055 (7th Cir. 1987); Erickson v. 
the state of a corporation's principal place of business in calculating relevant state interests.

\section{Doing Business Within the State}

Unlike the incorporation and principle place of business contacts, a corporation may "do business" in many states. For reasons unrelated to interest analysis, ${ }^{68}$ the law draws an artificial distinction between a corporation's "exclusive" principal place of business and the numerous other states in which a corporation "merely" does business. However, interest analysis concerns itself with a juridical entity's particular contacts with a state as a way of measuring that state's interest in applying its protective laws. Thus, the artificial distinction between the state of a corporation's principal place of business and the states in which a corporation does business need not divide the field between interested and non-interested states.

Although courts consider only one state as the corporation's principal place of business, ${ }^{70}$ this designation often does not reflect a significant difference between a corporation's principal place of business and other places where it does business. ${ }^{71}$ Consequently, both the principal place of business and a state in which the corporation merely does business could have similar interests in the corporation, for the difference in business, if any, might be minimal. Indeed, a small state in which a corporation "merely" does business could have a greater relative interest than a larger state in which it carries on a greater absolute quantity of business. Also, the state in which two corporations carry on equal levels of business activity could have a similar interest in each corporation, despite the fact that the state is the principal place of business for one corporation but is merely a place where the other larger corporation does business.

The doing business contact triggers a state's interest in a manner similar to the principal place of business contact, because it also implicates a state's concern in regulating the state's economy, maximizing corporate tax revenues, and protecting in-state employees and creditors. ${ }^{72}$ Interest analysts, though, recognize the doing business contact in a wholly unprincipled manner. In the overwhelming majority of cases, ${ }^{73}$ courts do not rec-

American Motors Corp., 683 F. Supp. 644 (E.D. Mich. 1987); Burley v. General Motors Corp., 650 F. Supp. 90 (D. Me. 1986); Camp v. Forwarders Transp., Inc., 537 F. Supp. 636 (C.D. Cal. 1982); Tiernan v. Westext Transp., Inc., 295 F. Supp. 1256 (D.R.I. 1969); Wallis v. Mrs. Smith's Pie Co., 261 Ark. 622, 550 S.W.2d 453 (1977); Hampshire v. Ford Motor Co., 155 Mich. App. 143, 399 N.W.2d 36 (1986); Griffith v. United Air Lines, 416 Pa. 1, 203 A.2d 796 (1964).

69. See supra note 60 and accompanying text.

70. But see supra note 64 (suggesting fictional nature of this judicial rule).

71. See id.

72. See supra notes $65-66$ and accompanying text.

73. In rare cases, courts recognize that the doing business contact implicates a state's protective interests. See In re Air Crash Disaster Near New Orleans, La., 821 F.2d 1147, 1177 (5th Cir. 1987) ("Louisiana has an interest in protecting not just its own resident-defendants but also entrepreneurs 
ognize the protective interests of states in which a corporation does business. ${ }^{74}$ Sometimes, a forum court will use corporate business activity within the forum state as a justification for applying liability-imposing forum law, but will refuse to recognize the protective interests of other states within which the corporation does business. ${ }^{75}$

\section{INTEREST ANALYSIS UNDERMINED}

Interest analysis therefore fails to recognize state interests in protecting corporations. The domicile-based protect-the-locals orientation at the heart of interest analysis leaves a corporation without any interested state, ${ }^{76}$ because even the most plausible corporate contacts-incorporation, principal place of business, and doing business-do not constitute the domiciliary status that implicates protective state interests. Corporate litigants as a class thus tend to be left out of the interest calculation, an unexplained result which is facially unfair and which has no justification within interest analysis theory. ${ }^{77}$

doing business in its State"); In re Air Crash Disaster Near Chicago, Ill., 644 F.2d 594, 614 (7th Cir.) cert. denied sub nom. Lin. v. American Airlines, 454 U.S. 878 (1981); Karavokiros v. Indiana Motor Bus Co., 524 F. Supp. 385, 387 n.1 (E.D. La. 1981) (recognizing Louisiana's interest in. protecting defendants who do business within state); of. Beasock v. Dioguardi Enter., Inc., 100 A.D.2d 50, 52, 472 N.Y.S.2d 798, 801 (1984) (recognizing New York's interest in applying its law prohibiting punitive damages in survival actions to "promote commerce within the state" by protecting out of state as well as resident defendants from excessive liability). In even these rare cases, courts fail to carry their insight to its logical conclusion: If corporate business in a state gives rise to an interest of that state in applying its laws, then no principled reason exists for not considering the relevant laws and interests of every state in which the corporation does significant business.

74. See, e.g., cases cited supra notes 67-68.

75. For example, in DeRemer v. Pacific Intermountain Express Co., 353 N.W.2d 694 (Minn. App. Ct. 1984), Minnesota plaintiffs brought a personal injury suit in Minnesota against a Nevada corporation for injuries sustained in an accident in South Dakota involving defendant's driver. The Minnesota Court of Appeals construed the choice of law issue as between Minnesota's comparative negligence law and South Dakota's contributory negligence law. As one justification for Minnesota's "clear governmental interest" in applying its plaintiff-benefiting law, the court stated: "[D]efendant corporation, although foreign to Minnesota, is licensed to do business in this state and exercises this privilege." Id. at 696. See also Hime v. State Farm Fire \& Cas. Co., 284 N.W.2d 829, 832 (Minn. 1979) (recognizing as reason to impose liability that corporate defendant "is licensed to do business in Minnesota and is subject to suit in our courts," but ignoring laws of other states in which corporation did business), cert. denied, 444 U.S. 1032 (1980); Hague v. Allstate Ins. Co., 289 N.W.2d 43, 47 (Minn. 1978) (recognizing as reason to impose liability "defendant's license to do business, and defendant's conduct of business in the state," but ignoring laws of other states in which corporation did business), aff d, 449 U.S. 302 (1981). The DeRemer court considered certification to do business in its state as one justification for ignoring the relevant laws of other states. In contrast, though, an individual's presence in a foreign state would not constitute a reason to ignore the interests of the individual's domicile, because the protection of that law would be preserved in a foreign ju-isdiction. Moreover, the DeRemer decision fails to explain why doing business in the forum state iustifies the forum's interest in applying its law to the exclusion of the law of every other state in which the corporation does business. "Doing business" might give rise to the injection of an interest in applying local law into the total interest calculation, but no principled reason exists for ignoring the relevant policies of the other states in which the corporation also does business.

76. For minor exceptions to this general truism, see cases cited supra notes $65 \& 73$. While these rare cases recognize that one type of corporate contact implicates a state interest, they ignare the interests of states with other equally relevant corporate contacts. See id.

77. In contrast, both the vested rights approach of the First Restatement and some applications of the "most significant relationship" test of the Second Restatement reach choice of law solutions 
This Section reconsiders interest analysis in light of the method's exclusion of corporations. Three fundamental difficulties appear. First, interest analysis cannot both accommodate corporate-protecting interests and solve choice of law problems that arise from this accommodation. Second, the anti-corporate bias inherent in interest analysis invariably leads to the selection of the law that maximally imposes corporate liability. Finally, the failure of the domicile connecting factor to reflect state interests in the corporate context undermines the core assumption of interest analysis.

\section{A. Proliferation of True Conflicts}

As currently practiced, interest analysis does not consider corporate contacts in identifying protective state interests. ${ }^{78}$ The discrimination against corporations can only be resolved by including corporations in the interest calculus. ${ }^{79}$ This in turn leads to a proliferation of relevant interests in interest analysis cases involving corporations.

through principles that are neutral as between individuals and corporations. The First Restatement generally directs a court to look to the law of the place where the legal rights in question vest. $L$. BRILMAYER, supra note 3, at 220 . In tort cases, this means the law of the place where the injury occurs. RESTATEMENT, supra note 3 , at $\$ \S 377-397$. If a person is injured in state X, the law of state $\mathrm{X}$ applies regardless of the nature of the litigant (individual or corporation) or of the litigant's affiliation with particular states. Thus, the First Restatement's focus on the place where the injury occurred is truly neutral between individuals and corporations.

The Second Restatement uses a "most significant relationship" test. Restatement (SECOND), supra note 2 , at $\S 145$. This test requires a court in a choice of law case involving torts to apply the law of the state which has the most significant relationship to the occurrence and the parties. Id. at $\S$ 145(1). The test is difficult to apply, for it combines almost antithetical considerations. A court must take into account the territorial contact points of Section $145, i d$. at $\S 145(2)$, in applying the general policy principles of Section $6, i d$. at $\$ 6$. As a result, the Second Restatement is an extraordinarily malleable document that the courts have used in radically different ways. Thus, courts invoke the Second Restatement to perform interest analysis, see, e.g., Murphy v. Colorado Aviation, 41 Colo. App. 237, 242 588 P.2d 877, 880 (1978); to break true conflicts generated by interest analysis, see, e.g., Erwin v. Thomas, 264 Or. 454, 506 P.2d 494 (1973); as a jurisdiction-selecting mèthod, see, e.g., Permagrain Prods. v. U.S. Mat \& Rubber Co., 489 F. Supp. 108, 111 n.1 (E.D. Pa. 1980); and as a vehicle for eclecticism, see, e.g., -General Elec. Co. v. Keyser, 275 S.E.2d 289, 295 (W. Va. 1981) (Second Restatement interpreted as hybrid of territorialism and Leflar's five factor test). See generally Reppy, supra note 6, at 655-66 (discussing eclecticism bred by Second Restatement). Because the Second Restatement lends itself to such various uses, generalizations about its treatment of corporations cannot easily be made. To the extent that courts rely on interest analysis concepts in emphasizing the policy factors of Section 6, the Second Restatement suffers from the same difficulties as interest analysis. See, e.g., Mitchell v. United Asbestos Corp., 100 Ill. App. 3d 485, 426 N.E.2d 350 (1981). To the extent that courts rely on Section 145 as a territorialist jurisdiction-selecting method, the Second Restatement tends to eliminate problems of unfairness against corporations in a manner similar to the First Restatement. See, e.g., Permagrain Prods. v. U.S. Mat \& Rubber Co., 489 F. Supp. 108 (E.D. Pa. 1980).

78. But see supra note 76.

79. Each of the corporate contacts discussed above gives rise to similar state concerns. See supra notes 49-51, 65-66,72 and accompanying text. All three contacts affect state revenues in a manner that does not allow for a principled distinction. See $i d$. While the incorporation contact might affect state financial interests less than the other two contacts, it more closely resembles the notion underlying the personal law principle. See supra text accompanying notes $48-49$. And while the principal place of business contact often implicates more serious revenue interests than a state in which the corporation does business. the difference need not be significant. See text accompanying notes 71-72. Thus, recognition of one contact as a trigger of state protective interests requires recognition of all three. 
This potential proliferation of interests defeats the one recognized achievement of interest analysis: the identification of false conflicts that allow the unproblematic application of the law of the only "interested" state. ${ }^{80}$ Recognition of the plethora of corporate-protecting interests in the corporate context would imply that courts rarely, if ever, discover a false conflict, because at least one state in which a corporation does business would probably have a corporate-protecting rule. Courts would therefore have to resort to the various second-order techniques ${ }^{81}$ used in resolving true conflicts, techniques considered by many to be as problematic as the methodology of the traditional vested rights approach. ${ }^{82}$ Currently, courts avoid this proliferation of interests and the intractable true conflicts that follow only by suppressing state interests in protecting corporations.

Offshore Rental Co. v. Continental Oil Co. ${ }^{83}$ illustrates the incoherence into which interest analysis courts fall. In Offshore, plaintiff corporation brought suit against defendant corporation to recover for the loss-of services of a key employee negligently injured on defendant's premises in Louisiana. Plaintiff was incorporated in California and maintained its principal place of business there, but did significant business in Louisiana and alsewhere; defendant was incorporated in Delaware, headquartered in New York, and did business in Louisiana, California and elsewhere. California law allowed recovery, Louisiana law denied it. In making the crucial identification of each corporate litigant with a particular state, the court identified California as the plaintiff's "home" and Louisiana as the

80. See Ely, supra note 7, at 176.

81. See supra note 10.

82. See id. The proliferation of corporate-protecting interests creates resolution difficulties that are significantly more intractable than the traditional two-state true conflict. With large corporate litigants, the interests of up to fifty states could be implicated. Not only is the research, identification, and measurement of dozens of interests impracticable, but any resolution of these many conflicting interests will be unsatisfactory. Cf. Miller \& Crump, Jurisdiction and Choice of Law in Multistate Class Actions After Phillips Petroleum Co. v. Shutts, 96 YALE L.J. 1, 64-66 (1986) (discussing enormous difficulty for judges "of organizing and following fifty or more different bodies of complex substantive principles" in nationwide class action choice of law disputes).

For example, in System Operations, Inc. v. Scientific Games Dev. Corp., 555 F.2d 1131, 1137-38 (3rd Cir. 1977), the court acknowledged that the states in which the corporate litigants did business as well as their principal places of business all had "substantial interest[s] in having their respective laws of product disparagement applied." The court despaired in the face of its choice of law task: "Given the facts of this case, . . . a New Jersey court would be hard pressed to single out any one state as having the most significant interest in having its law applied." Id. at 1138.

Judge Weinstein, faced with the analogous difficulty of ascertaining and analy.ing the numerous state interests in the Agent Orange litigation, stated: "Any narrow and mechanical state choice of law system simply collapses under the weight of the multiplicity of contacts, policies and unarticulated or conflicting state interests . . . . There is no rational method by which a state could choose one state's law to govern some or all of the issues in the case ...." In re "Agent Orange" Prod. Liab. Litig., 580 F. Supp. 690, 703, 706 (E.D.N.Y. 1984).

83. 22 Cal. 3d 157, 583 P.2d 721, 148 Cal: Rptr. 867 (1978).

84. The laws of the two states differed on the question of whether a corporation could maintain an action for damages arising out of personal injury to one of its employees. 22 Cal. $3 \mathrm{~d}$ at 160,583 P.2d at 723, 148 Cal. Rptr. at 869. 
defendant's. The court went on to find a true conflict and, using a comparative impairment break device, ${ }^{85}$ applied the law of Louisiana.

The interesting aspect of Offshore concerns not the final choice of law but rather the method of locating corporate parties for purposes of determining interests. ${ }^{86}$ True to its domicile presuppositions, the court "located" each corporate party in only one state. Plaintiff apparently was assigned to California not because it was incorporated there, but rather because California was its principal place of business. ${ }^{87}$ Defendant, on the other hand, was assigned to Louisiana by locating it at the site of its corporate division that became involved in the litigation. The court offers no explanation for this arrangement of litigant/state identifications. In particular, it does not explain why: (a) California counts as plaintiff's home because of the principal place of business contact and yet defendant's principal place of business is ignored; (b) Louisiana counts as defendant's home state because of its business within the state, but plaintiff's business there does not give rise to a similar identification; (c) the dozens of other states in which both corporate litigants do business are ignored; or (d) the place of incorporation is insignificant in the interest calculation. The court, seemingly bound by the one party/one state domicile rule, appears to have made its identification ad hoc. It narrowed the field of interested states in a way that allowed for a manageable resolution of the conflict, but only by making unprincipled corporation-state identifications, and by ignoring, without explanation, states that were at least as interested as those recognized. ${ }^{88}$

85. Comparative impairment analysis resolves true conflicts by considering "which states' interest would be more impaired if its policy were subordinated to the policy of the other state." 22 Cal. $3 \mathrm{~d}$ at 165,583 P.2d at 726, 148 Cal. Rptr. at 872. See generally Baxter, supra note 10 (explaining theoretical underpinnings of comparative impairment doctrine).

86. See Reppy, supra note 6, at 672 n.133.

87. The court observed that no party had urged application of Delaware law even though Delaware was the state in which defendant was incorporated. Offshore, 22 Cal. $3 \mathrm{~d}$ at $161 \mathrm{n} .2,583 \mathrm{P} .2 \mathrm{~d}$ at 723 n.2., 148 Cal. Rptr. at 869 n.2. "The parties and the court apparently agreed that a corporate litigant should not, for purposes of interest analysis, be located in a state merely because it is incorporated there." Keppy, supra note 6, at 672 n.133. Since incorporation was deemed insignificant, the identification of the plaintiff with California must have been based on the principal place of business contact. Aithough the parties in Offshore failed to urge the application of the law of Delaware as defendant's state of incorporation, the court would have considered Delaware's interests if it viewed them as relevant, for as the court said, "we make our own determination of . . . policies and interests" independently of the litigants suggestions. The court gave no independent reason for its refusal to consider Delaware law. Offshore, 22 Cal. $3 \mathrm{~d}$ at 163 n.5, 583 P.2d at 725 n.5, 148 Cal. Rptr. at 871 n.5.

88. Offshore is a relatively unusual choice of law torts case because it involves a corporate plaintiff as well as a corporate defendant. In a case of this kind, a court performing interest analysis will necessarily find an interest that benefits one of the corporate litigants. As Offshore shows, courts can find this interest only by identifying parties with states in an unprincipled and tendentious manner. However, Offshore does not exhaust the possibilities for distortion in cases in which all litigants are corporations. For example, in Eastern Refractories Co. v. Forty Eight Insulations, Inc., 658 F. Supp. 197 (S.D.N.Y. 1987), an action between corporate litigants sounding in negligence and strict liabilty, the court stated that it would apply the law of the jurisdiction of "greatest interest" and would consider as significant connecting factors the parties' domiciles and the locus of the tort. Id. at 200. However, even after perfunctorily reciting the principal place of business and place of incorporation of 
As Offshore shows, interest analysis cannot simultaneously adhere to its domicile premise and treat corporations in a principled manner. Interest analysis is impaled on the horns of a destructive dilemma: It can generate false or relatively small conflicts only by distorting legitimate state interests in corporations, which is unfair to corporations and antithetical to its own premises, or it can recognize these more ubiquitous state interests in corporations, but only at the cost of generating unresolvable controversies.

\section{B. The Law of Maximum Corporate Liability}

In systematically failing to recognize corporate-protecting interests, interest analysis frequently leads to the choice and application of the law which imposes maximum corporate liability ${ }^{80}$ With the aid of liberal personal jurisdiction laws ${ }^{80}$ and the Klaxon doctrine, ${ }^{91}$ plaintiffs sue corporations in interest analysis fora with pro-plaintiff laws. ${ }^{92}$ Because corporateprotecting interests are not recognized, corporate liability follows. ${ }^{\text {s3 }}$

each of the corporate litigants, the court ignored these connecting factors and failed to consider which state, if any, might be interested in protecting any of the plaintiff or defendant corporations. Instead, without analysis the court applied the law of Florida, the state of injury. See also Morgan Guaranty Trust Co. v. Garrett Corp., 625 F. Supp. 752 (S.D.N.Y. 1986) (failing to consider any interests of numerous states in which both plaintiff and defendant corporations had various contacts; focusing exclusively on interests of states in which two decedents were domiciliaries but deciding in accordance with law of place of injury).

89. See, e.g., Gore v. Northeast Airlines, 373 F.2d 717 (2d Cir. 1967) (applying New York's limitless wrongful death statute rather than Massachusetts' limited one); DeRemer v. Pacific Intermountain Express Co., 353 N.W.2d 694 (Minn. Ct. App. 1984) (applying Minnesota's comparative negligence rather than South Dakota's contributory negligence rule); Pfau v. Trent Aluminum Co., 55 N.J. 511, 263 A.2d 129 (1970) (refusing to apply Iowa's guest statute).

90. The power of a state to assert personal jurisdiction over a party has expanded greatly since the articulation of the "minimum contacts" standard in International Shoe Co. v. Washington, 326 U.S. 310 (1945). The period following International Shoe has been marked by a proliferation of longarm statutes and a generally permissive trend in due process regulation of personal jurisdiction. See Burger King Corp. v. Rudzewicz, 471 U.S. 462 (1985); Calder v. Jones, 465 U.S. 783 (1984). Although the Supreme Court has delineated the outer limits of the assertion of personal jurisdiction, see Asahi Metal Indus. Co. v. Superior Court, 107 S. Ct. 1026 (1987); World Wide Volkswagen Corp. v. Woodson, 444 U.S. 286 (1980), the minimum contacts test still provides a plaintiff with a large choice of fora in multistate cases.

91. A federal court sitting in diversity jurisdiction is required to apply the choice of law rules of the state in which it sits. Klaxon Co. v. Stentor Elec. Mfg. Co., 313 U.S. 487 (1941).

92. Shreve, Interest Analysis as Constitutional Law, 48 OHIо ST. L. J. 51,59 (1987) ("Choiceof-law-motivated forum shopping [has grown] in proportion to the increase in the number of courts jurisdictionally competent to hear the same case.").

93. Usually, plaintiffs seek interest analysis courts in states with favorable law, which the forum applies. Application of pro-forum law was encouraged by the Supreme Court's decision in Allstate Ins. Co. v. Hague, 449 U.S. 302 (1981), which held that a state's decision to apply its substantive law is unconstitutional only if the aggregation of the parties, the occurrence, and th: state renders arbitrary or fundamentally unfair the choice of that state's law. Most scholars believe Hague eliminates any serious constitutional constraints on choice of law. See, e.g., R. WeINTRAu'B, supra note 46, $\$ 9.2 \mathrm{~A}$, at 525 . It remains to be seen whether the Supreme Court holding in Phillips Petroleum Co. v. Shutts, 472 U.S. 797, 822 (1985), that the application of forum law to all claims in a complex multistate class action in which $98 \%$ of the litigants had no contact with the forum was "sufficiently arbitrary and unfair as to exceed constitutional limits," represents a heightened scrutiny in constitutional limits on choice of law. See R. Weintraub, supra note 46, $\$ 9.2 \mathrm{~A}$, at 527-29. But of. Sun Oil Co. v. Wortman, 108 S. Ct. 2117 (1988) (Kansas did not exceed constitutional limitations on choice of law by applying its own statute of limitations to claims of residents of other states). 
Moreover, the failure to recognize corporate-protecting interests creates a gap that allows for the injection of extraneous anti-corporate factors into the interest calculus. This occurs most blatantly when a court "discovers" an anti-corporate state interest in what would normally be a classic "no interest"94 or "unprovided-for"9s case. For example, in Wuerffel $v$. Westinghouse Corp. ${ }^{96}$ a New Jersey plaintiff sued Drexel University, a Pennsylvania not-for-profit corporation, for an injury that occurred in New Jersey under a program sponsored by the defendant. New Jersey had a pro-defendant charitable immunity statute; Pennsylvania did not. The case thus should have presented a classic "no interest" case, because under the standard protect-the-locals orientation, New Jersey had no interest in applying its pro-defendant law to protect a Pennsylvania defendant, and Pennsylvania had no interest in applying its pro-plaintiff law to protect a New Jersey plaintiff. Nonetheless, the court applied the Pennsylvania law because of "Pennsylvania's interest in demanding accountability of its corporations." $"{ }^{2}$ The court thus ignored the protect-the-locals philosophy and construed the scope of Pennsylvania's law differently than it would have in the individual context because of a special interest in imposing liability on corporations. ${ }^{\text {98 }}$

Several factors-all irrelevant from an interest analysis perspective-help to explain this extra layer of anti-corporate bias. First, courts sometimes tacitly assume that corporations are less "real" than persons and thus do not deserve similar protection of state laws. ${ }^{99}$ Corporations

94.

The classic 'no interest' case is one in which the plaintiff's state has a law favorable to the defendant and the defendant's state has a law favorable ... to the plaintiff. The term 'no interest' comes from the argument that neither state is interested in having its own law apply. The plaintiff's state has no interest in protecting the defendant who comes from another state and the defendant's state has no reason to give the plaintiff more compensation than he would get under the law of his own state.

R. Weintraub, supra note $46, \S 6.23$ at 333 .

95. See B. CuRRIE, supta note 6 , at 152 .

96. 148 N.J. Super. 327,372 A.2d 659 (1977).

97. 148 N.J. Super. at $335 ; 372$ A.2d at 663.

98. See also Gravina v. Brunswick Corp., 338 F. Supp. 1, 4 (D.R.I. 1972) (recognizing, in what should have been classic no interest case, Illinois' interest in applying its privacy laws to impose liability on Illinois corporation); Kaiser-Georgetown Community Health Plan, Inc. v. Stutsman, 491 A.2d 502, 509-10 (D.C. App. 1985) (in what should have been classic no interest case, applying District of Columbia's malpractice law to impose liability on District of Columbia corporation because of District's "significant interest . . . in holding corporations liable for the full extent of the negligence"); Johnson v. Spider Staging Corp., 87 Wash. 2d 577, 583, 555 P.2d 997, 1002 (1976) (imposing liability on Washington corporation in what should have been classic unprovided-for-case because Washington's "legitimate interest" in "full compensation is clearly advanced by the application of its own [limitless wrongful death statute]").

99. Although the nature of the corporate entity has long been subject to debate, see Horwitz, supra note 32, at 173 (discussing historical debate over corporate form); Comment, The Personification of the Business Corporation in American Law, 54 U. CHI. L. REv. 1441 (1987), it is generally recognized today that corporations are entities capable of bearing rights and duties. See M. DANCOHEN, supra note 4 , at 14 \& n.8 (corporate entity theory debate won by realists); see also id. at 13-25 ("organizational revolution" in the last 100 years has displaced traditional nineteenth century view of corporations, requiring new cognitive structures to incorporate modern corporate reality); 
also seem less deserving of state law protection because they cannot participate in the formation of these laws through voting. ${ }^{100}$ Finally, modern tort law trends reinforce this tendency to impose liability on corporations by viewing them as deep pockets and efficient risk-spreaders. ${ }^{101}$ Indeed, several scholars in the interest analysis tradition have called directly for reliance on state-transcendent tort law trends to spread losses on deep pocket defendants. ${ }^{102}$

These factors might separately or in conjunction constitute a plausible basis for choice of law. For example, a choice of law rule that applies the law of the state that maximally imposes corporate liability could legitimately be grounded in arguments about political fairness or social equality. However, the basis for such choice of law rules differs dramatically from the foundational philosophy of interest analysis-respect for sovereign state interests. ${ }^{103}$ To the extent that interest analysts embrace such tacit assumptions and such explicit liability-imposing choice of law rules, they have rejected their own first principles.

Comment, supra (detailing rise of corporate personality and autonomy); $f$. Garret, Communality and Existence: The Rights of Groups, 56 S. CAL. L. REv. 1001 (1983) (arguing that moral and legal rights of corporations have foundation independent of rights of individuals or society).

100. However, to the extent that a state's interest in applying its protective law is a function of the burdens assumed by its subjects, this assumption may be fallacious. The scope of a law's protection is not limited to those who participated in its creation. See Brilmayer, Shaping and Sharing in Democratic Theory: Towards a Political Philosophy of Interstate Equality, 15 FLA. ST. U.L. REV 389,411 (1987). If the benefits of a law were limited to those who participated in its passage, then the basis of state coercion over outsiders - that one who receives the benefits of law must also bear its burdens-would be undercut. Id. Professor Brilmayer attempts to use this argument to undermine (among other things) the general unfairness of the interest analysis protect-the-locals orientation, in which outsiders bear the burdens of state law but not all of its benefits. The analysis can be applied to corporations in a different way: Although outsiders in the sense of being excluded from the electoral process, corporations are still subject to the burdens of state law, and thus should also receive its benefits and protection. Moreover, corporations do participate in law formation through means other than voting, such as political contributions, see, e.g., Epstein, PACS and the Modern Political Process, in The IMPact of THE Modern Corporation 399 (B. Block, ed. 1984), and threats of relocation, see, e.g., Current Topic, Sports Franchise Relocation: Competitive Markets and Taxpajer Protection, 6 YAle L. \& Pol'y Rev. 429 (1988) (authored by John D. Beisner).

101. See, e.g., R. Posner, Economic ANalysis of LAw (2d ed. 1977). A glance at recent state tort reform legislation suggests that this liability-maximizing tendency is in reverse. See Priest, The Current Insurance Crisis and Modern Tort Law, 96 YALE L.J. 1521, 1587-88 \& nn. 257-62.

102. See, e.g., R. Weintraub, supra note $46, \S 6.4$, at 284-85 (advocating law which best distributes losses); Morrison, Death of Conflicts, 29 VILL. L. Rev. 313, 338 (1983) (advocating choice of "more fully compensating tort law"); Sedler, The Governmental Interest Approach to Choice of Law: An Analysis and a Reformulation, 25 UCLA L. REv. 181, 235 (1977) (advocating use of common state policies promoting recovery in unprovided-for-tort-cases); Weinburg, On Departing From Forum Law, 35 MERCER L. REv. 595, 624 (1985) (advocating reliance on policies favoring risk spreading and compensation).

The reliance by these scholars on state-transcendent tort law trends to impose liabilty on deep pocket defendants seems contradictory in light of the fact that current state tort law trends are moving sharply in the direction of limiting liability. See Priest, supra note 101, at 1587-88 \& nn. 257-62.

103. See Brilmayer, supra note 7, at 399 ("abiding purpose of [interest analysis] is case-by-case implementation of state policies"). 


\section{State Interests Not Reflected in Corporate Context}

Interest analysis purports to replace the abstract rules of the traditional method that failed to consider legitimate state interests with a more realistic approach that takes into account the various competing state policies at issue. ${ }^{104}$ Interest analysis theory assumes that the domicile contact somehow accurately triggers a state's interest in a matter. However, the domicile orientation at the heart of interest analysis almost always leads courts to recognize state interests only in protecting local persons and is inherently incapable of cognizing the variety of interests different states have in protecting corporations.

Interest analysis is successful only to the extent that the connecting factors on which it relies truly reflect state interests. This is the rationale upon which the entire system rests. ${ }^{105}$ If the types of contacts recognized in determining state law protection fail to reflect each state's interest in a particular matter-as with corporations-the primary justification for interest analysis is undercut and the system is no longer tenable. ${ }^{108}$

\section{GoNCLUSION}

The scheme within which interest analysis identifies state interests is grounded in assumptions about persons that do not apply to corporations. Because corporations do not assimilate well into interest analysis' central domicile framework, interest analysis as currently practiced ignores a variety of state interests in protecting corporations. The refusal to recognize corporate-protecting interests has no justification within interest analysis theory, and leads courts to consider anti-corporate factors that should be irrelevant. Moreover, recognition of corporate-protecting interests reveals difficulties that violate the methodology's foundational principles. Thus, the application of interest analysis to corporate entities proves to be the reductio ad absurdum of the method. ${ }^{107}$

104. Id. at 392 .

105. See Corr, supra note 6, at 654 (link between domicile or residence and state interests is "pivot on which interest analysis usually turns ... the linkage [between domicile and state interests] has become so strong that the relationship between [them] seems to have fused the two concepts into a single entity").

106. The selection of a single contact for corporations-for example the place of incorporation-as a proxy for domicile will not address this difficulty. While the arbitrary selection of just one corporate contact as the trigger of protective state interests might preclude many of the multipleinterest logistical problems that arise from applying interest analysis to corporations, see supra notes 78-82, and accompanying text, it would do so only at the price of severing the connection between triggering contact and protective interest that lies at the heart of interest analysis.

107. For a brief discussion of the application of this Note's critique to the methodologies of the First and Second Restatements, see supra note 77. 